\title{
Opowieści z lasu deszczowego Horacia Quirogi w perspektywie antropologii literackiej
}

\author{
Agnieszka Możejko \\ Uniwersytet Gdański \\ Wydziat Filologiczny, Instytut Filologii Polskiej \\ E-mail:mozejko2211@gmail.com \\ tutor: dr hab. Magdalena Horodecka, prof. UG \\ Uniwersytet Gdański \\ Wydziat Filologiczny, Instytut Filologii Polskiej
}

Stowa kluczowe: Horacio Quiroga, Cuentos de la selva, antropología literacka, literatura argentyńska

Współczesna humanistyka szeroko czerpie z antropologii kulturowej, pojęcie antropologii literackiej nie jest jednak jednoznacznie zdefiniowane. Niektórzy badacze upatrują w literaturze źródła wiedzy antropologicznej, inni w pisarzach widzą antropologów - połączenie antropologii kulturowej i literaturoznawstwa może mieć różnorodne oblicza. Mimo że badania interdyscyplinarne na pograniczu humanistyki i antropologii mogą skupiać się na różnych aspektach obu dziedzin, niezmiennym jednak pozostaje fakt, że zarówno humanistyka, jak i antropologia w centrum swoich zainteresowań stawiają człowieka (Łebkowska, 2007, s. 15).

Na potrzeby tego artykułu posługuję się antropologią literacką jako metodą umożliwiającą analizę tekstu pod względem przejawiających się w nim śladów obecności różnych kultur nie w wymiarze szczegółów etnograficznych, lecz wzajemnych inspiracji artystycznych przenikających się kultur. Cuentos de la selva [Opowieści z lasu deszczowego] Horacia Quirogi stanowią w tej perspektywie materiał cenny, gdyż Quiroga był wywodzącym się z Ameryki Południowej autorem, który nie krył inspiracji twórczością Edgara Allana Poego i Rudyarda Kiplinga.

Przekład, którym posługuję się na potrzeby artykułu, jest owocem mojej samodzielnej nauki języka hiszpańskiego. Zdecydowałam się na wykorzystanie własnego przekładu ze względu na niedostatki tłumaczeń na język polski Cuentos de la selva powstałych odpowiednio w 1950 i 1976 roku. Jako przykład problemów, które napotykamy w tych tłumaczeniach, posłużyć może fragment pierwszego utworu w zbiorze odnoszący się do postaci myszy Pereza - zaczerpniętej z folkloru krajów hiszpańskojęzycznych:

Pero un ratón de la ciudad - posiblemente el ratoncito Pérez - encontró a los dos viajeros moribundos (Quiroga, 2018, p. 16). 
Ale miejska myszka - możliwe, że była to Mickey Mouse - spotkała wyczerpanych podróżnych (Quiroga, 1950, s. 11).

Ale pewna miejska myszka - może ją znacie? spotkała na swej drodze umierających podróżników (Quiroga, 1976, s. 210).

W obu przekładach tego rodzaju zmian, usunięć jest więcej, między innymi w przekładzie z 1976 z El paso del Yabebirí [Przeprawa przez rzekę Yabebirí] usunięto wzmianki o języku guarani. Do tego w tłumaczeniu z 1950 podjęto decyzję o tłumaczeniu tigre jako tygrys, a nie jaguar, co jest nieadekwatne względem zarówno realiów geograficznych, jak i językowych. Poza tym przekłady są bardzo dosłowne, co stanowi jednocześnie ich zaletę i wadę, gdyż z jednej strony są to przekłady wierne, lecz z drugiej utwory tracą na tym literacko - w oryginale pisane są bardziej dowcipnym językiem niż wskazywałyby na to tłumaczenia.

Horacio Quiroga (1878-1937) to pisarz ze względu na biografię jednocześnie urugwajski i argentyński, zaliczany do grona najpopularniejszych autorów obu tych krajów. Jego najbardziej znane dzieło, zbiór baśni Cuentos de la selva (1918), ma stałe miejsce w kanonie literatury, zostało wpisane na listę lektur szkolnych dla szkół podstawowych w Argentynie i Urugwaju (Finocchiaro, 2018) i doczekało się niezliczonych wznowień i adaptacji. W hiszpańskojęzycznych encyklopediach Quiroga widnieje głównie jako wzorujący się na Edgarze Alanie Poem autor zebranych w tomie Cuentos de amor, locura y de muerte [Opowieści o miłości, szaleństwie i śmierci] opowiadań dla dorosłych, którego życie naznaczone zostało przez pasmo tragedii i samobójstw bliskich, jednak to właśnie skierowane do dzieci Cuentos de la selva pozostaje jego najczęściej czytanym dziełem (Franco, 1993, p. 198).
Pomimo często makabrycznej treści Cuentos de la selva, zbiór ten w sferze wydawniczej istnieje jako dzieło o infantylnym charakterze przeznaczone dla najmłodszych czytelników. Dla przykładu, oto fragment opisowy z El paso del Yabebirí w zestawieniu z okładkami kilku wydań (Ryc. 1-3):

Yabebirí wyglądała jak rzeka krwi. Płaszczki umierały setkami, ale jaguary również były w bardzo ciężkim stanie i wycofywały się, aby pokładać się na plaży i ryczeć z bólu, gdy zaczynała pokazywać się opuchlizna. Poranione pazurami płaszczki nie poddawały się, walczyły, by bronić przejścia. Niektóre wyrzucane w powietrze spadały z powrotem do rzeki i spieszyły ponownie do walki (tłumaczenie własne).

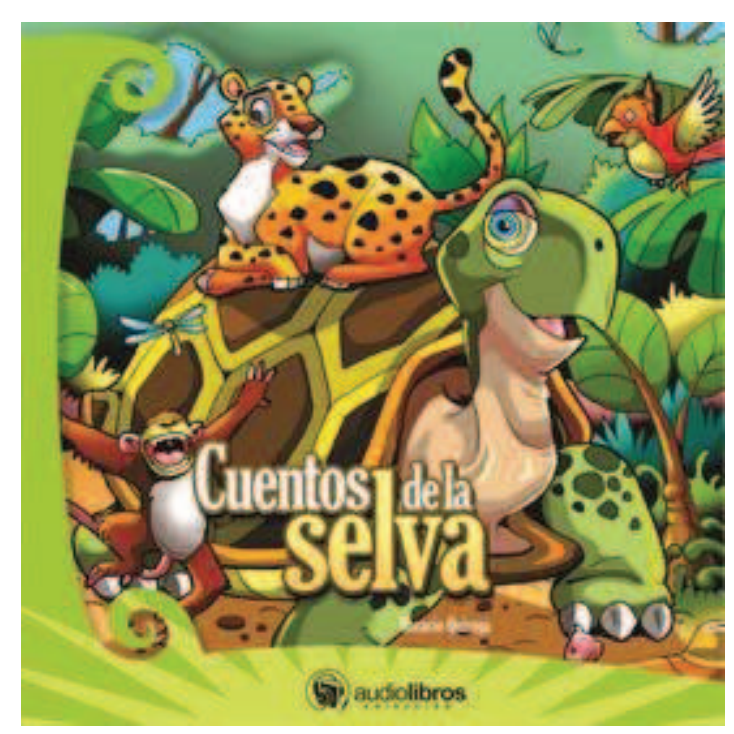

Ryc. 1. Okładka audiobooka Cuentos de la selva. (https://www.kobo.com/ie/en/audiobook/cuentosde-la-selva-13, dostęp: 6.01.20)

Bardzo kolorowe okładki przedstawiają rysowane w uproszczony sposób uśmiechnięte zwierzęta. Adresowanie pozycji do dzieci zgodne jest z oryginalnymi okolicznościami powstania dzieła, które autor napisał dla swoich dzieci, Eglé i Darío, ich charakter jednak przekracza współczesne granice literatury dziecięcej, a zabieg stosowany przez wydawców przywodzi na myśl 


\section{Tutoring Gedanensis}

dzieje poddawania kolejnym cenzurom baśni zebranych przez braci Grimm (Darnton, 2012, s. 28-29) czy Matej syrenki Hansa Christiana Andersena, której studio animacji Disney dopisało szczęśliwe zakończenie (Clements, Musker, 1989). W przypadku Quirogi nie ingerowano w fabuły utworów, lecz w podobny sposób, być może wzorowany na losach europejskich utworów, przeniesiono je w inne ramy estetyczne. Warto zaznaczyć, że wydania infantylizujące treść utworu nie są jedynymi dostępnymi na rynku, ale ich obecność jest na tyle szeroka, że można mówić o trendzie.

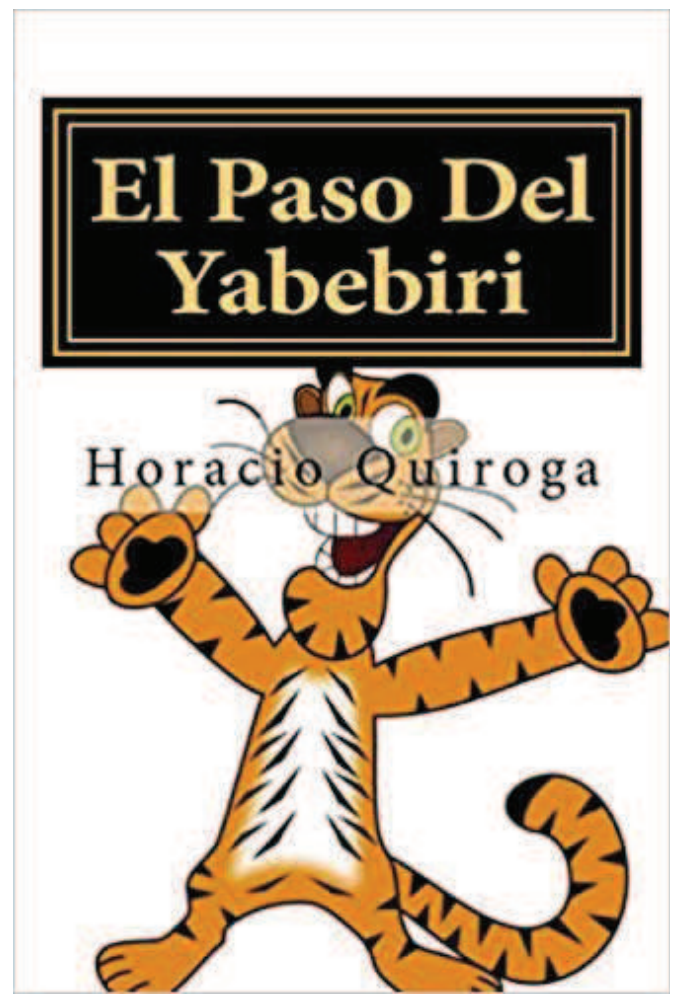

Ryc. 2. Okładka jednego z opowiadań ze zbioru Cuentos de la selva, El paso del Yabebirí.

(https://www.amazon.com/El-Paso-Del-Yabebiri-

Spanish/dp/1530876486, dostęp: 6.01.20)

Same utwory Quirogi literacko kontynuują europejską tradycję baśni i bajki zwierzęcej pomimo przeniesienia miejsca akcji na inny kontynent. Cuento ( $w$ języku polskim najbliższym tłumaczeniem jest termin opowiadanie) jako gatunek właściwy hiszpańskojęzycznej literaturze Ameryki Środkowej i Południowej pochodzi zarówno z podań i legend prekolumbijskich, jak i tekstów europejskich obecnych na tym terenie od czasu kolonizacji, przy czym zauważalna jest tendencja do globalizacji kultury Ameryki Łacińskiej i podążania za wzorcami z Ameryki Północnej i Europy (Ortiz Aguirre, 2017, p. 25). Do tej grupy twórców zalicza się Quiroga podający wśród swoich inspiracji Kiplinga i Poego (Rogers, 2006).

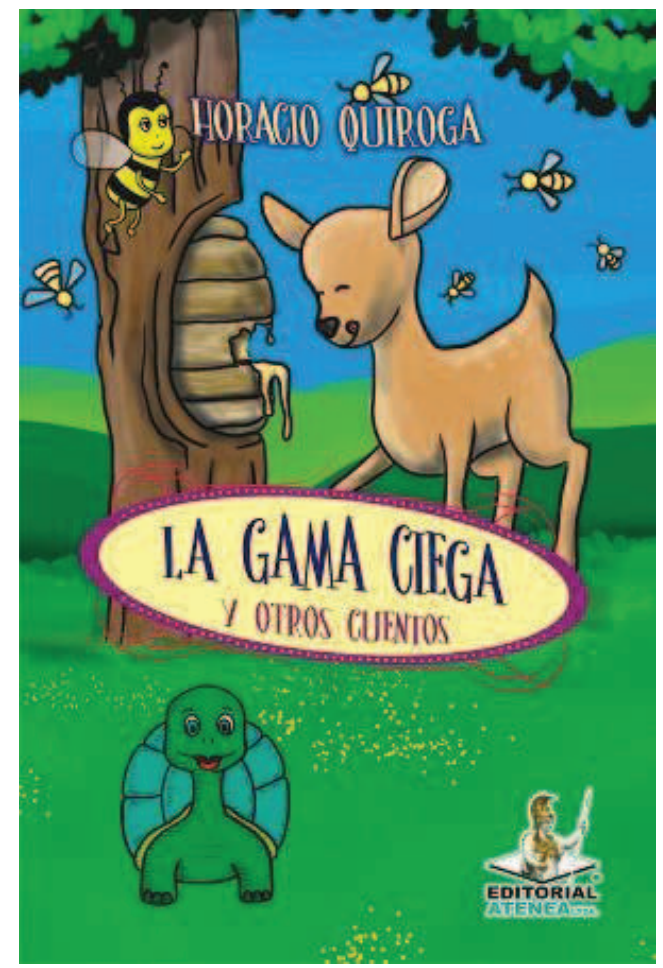

Ryc. 3. Okładka jednego z opowiadań ze zbioru Cuentos de la selva, La gama ciega. (http://www.editorialatenea.com.co/portfolio_item/la-gama-ciega/, dostęp: 6.01.20)

Wpływy tekstów europejskich widać w sposobie konstruowania symboliki zwierząt. Ze względu na różną faunę Europy i Ameryki Południowej rzadko zdarza się, aby w Cuentos de la selva pojawiały się te same zwierzęta alegorycznie odsyłające do cech 
ludzkich co w kanonie europejskim (nie jest to jednak niespotykane, tak samo jak w literaturze europejskiej pszczoły u Quirogi wyróżniają się pracowitością, a węże w duchu symboliki chrześcijańskiej pojawiają się w rolach antagonistów), lecz obecny jest schemat symbolicznego przyporządkowania gatunkowi wybranej cechy ludzkiej, na tej zasadzie flamingi oznaczają głupotę, a jaguary agresję.

Jaguar jest szczególnie ciekawym przykładem, ponieważ Quiroga odrzuca znaczenie przypisywane mu przez rdzennych mieszkańców Ameryki Środkowej i Południowej, dla których było to zwierzę święte, symbolizujące siłę, mądrość oraz ochronę (Urcid Serrano, 2005). Zamiast tego wykorzystuje je w podobnej roli, jaką w europejskich opowieściach pełni wilk - jest to zagrożenie czające się w lesie. Idąc tropem wypowiedzi samego autora powołującego się na Księgę dżungli Kiplinga jako ważną inspirację podczas tworzenia Cuentos de la selva, do której hiszpańskiego tytułu (Libro de la selva) odwołał się w tytule swojego zbioru, zauważyć można podobieństwo pomiędzy powracającą w Cuentos de la selva figurą jaguara a tygrysem Shere Khanem, antagonistą Księgi dżungli (Kipling, 1950). Mowa nie o podobieństwach fabularnych, ale prze-rażeniu, jakie wzbudza jego obecność.

Krzywdzącym byłoby jednak stwierdzenie, że Quiroga jest jedynie kopistą zagranicznych wzorców. Pomimo czerpania jawnych inspiracji z literatur obcych, jego przedstawienie lasu jest unikatowe. Diego Fabián Arévalo Viveros w artykule El cuento es la selva: lectura crítica-ecológica de los Cuentos de la selva de Horacio Quiroga (Arévalo Viveros, 2019) dokonał analizy lingwistycznej dialogów zwierząt pojawiających się w osadzonych w lesie opowiadaniach Quirogi, stawiając tezę, że ich język jest językiem lasu. Zwierzęta zwykle komunikują się za pomocą krótkich zdań wyrażających panujące w lesie prawa i zależności pomiędzy gatunkami, rozmowy te nie odnoszą się do abstrakcji i nie przypominają rozmów między ludźmi.

- To nie pończochy! - krzyczały żmije - Wiemy, co to jest! Oszukano nas! Flamingi zamordowały nasze siostry i teraz noszą ich skóry na nogach! To pończochy z koralowych żmij!

Po usłyszeniu tego przerażone wyjściem na jaw prawdy flamingi chciały uciekać, ale były tak zmęczone, że nie mogły podnieść nawet jednej nogi. Właśnie wtedy koralowe żmije rzuciły się na flamingi, oplotły ich łapy swoimi ciałami i zaczęły gryźć i niszczyć pończochy. Zrywały je z flamingów po kawałku, wściekle wbijając się kłami w nogi ptaków, aby pomścić swoje siostry (tłumaczenie własne).

Miejsce człowieka w świecie Quirogi zasługuje również na oddzielne omówienie. W Cuentos de la selva ludzie jako zbiorowość i człowiek jako jednostka to dwa różne byty. Ludzie są zagrożeniem dla świata zwierząt, a ich obecność w lesie jest szkodliwa. W baśni La guerra de los yacarés [Wojna kajmanów] cywilizacja, którą niosą ze sobą ludzie, oznacza zgubę kajmanów i musi zostać zatrzymana, co ostatecznie prowadzi do tytułowej wojny. W baśni La abeja haragana [Leniwa pszczoła] obraz ludzi nie jest tak jednoznacznie zły, ponieważ kradną oni pszczołom miód, ale, jak zauważa główna bohaterka, robią to dlatego, że są od pszczół inteligentniejsi, tak więc nie łamią leśnych praw. W obu przypadkach jednak ludzie szkodzą zwierzętom, a życie w lesie byłoby lepsze bez ich obecności. W jedynej baśni, w której rola ludzi nie jest pasożytnicza względem natury, Las medias de los flamencos [Pończochy flamingów], ich obraz wciąż jest negatywny.

Człowiek jako jednostka to zupełnie inna postać. Mężczyźni pojawiający się w baśniach La tortuga gigante [Wielki żółw], El loro pelado [Oskubana papuga], La gama ciega [Ślepa sarna], Historia de dos cachorros de coatí y dos cachorros de hombre [Historia 
o dwóch małych koati i dwóch małych dzieciach] i El paso del Yabebirí są odważni i pomocni, przyjaźnią się z wieloma zwierzętami i niosą im pomoc, wielokrotnie wykazując się współczuciem i troską. Kontrast pomiędzy człowiekiem a ludźmi najbardziej widoczny jest w El paso del Yabebirí, w którym szlachetny człowiek przeciwstawia się praktyce ludzi polegającej na zrzucaniu do rzeki dynamitu i uśmiercaniu milionów ryb, aby ułatwić sobie połów. Czytamy, że człowiek ten nie ma przyjaciół poza rybami, a więc odstaje od społeczności ludzkiej. Co ważne, na samym początku baśni pojawia się fragment: „Nie był przeciwny zjadaniu ryb z rzeki, ale nie chciał zabijać bez celu milionów zwierząt" (tłumaczenie własne). Mężczyzna nie był przeciwny zabijaniu ryb w celu zdobycia pożywienia, buntował się przeciwko zabijaniu ryb ponad miarę, a więc naruszaniu panującego w naturze balansu. Tak samo balans chciały naruszyć jaguary, zabijając człowieka w zemście za to, że zranił jednego z nich.

- Ach, już widzę, o co chodzi. Jesteście panie podłe! Dajcie mi przepłynąć!

- Nie damy! - odpowiedziały płaszczki.

- Dajcie!

- Nie damy! To dobry człowiek! Nie masz prawa go zabić!

-Zranił mnie!

- Obaj się zraniliście! Prawo dżungli, drogi panie, a tutaj jest pod naszą ochroną! Przejścia nie ma! (tłumaczenie własne).

Jak powiedziały płaszczki, człowiek i jaguar zranili się nawzajem, co oznacza, że nie zostały naruszone zasady panujące w lesie, zemsta była więc niepotrzebna.

Spośród postaci ludzkich jednoznacznie pozytywne pozostają również postaci dziecięce, pojawiające się w baśniach El loro pelado oraz Historia de dos cachorros de coatí y dos cachorros de hombre. Przyczyn takiego stanu rzeczy można szukać w symbolicznym przypisywaniu dzieciństwu niewinności lub fakcie, że zbiór Cuentos de la seIva jest przeznaczony dla dziecięcych czytelników, najbardziej prawdopodobne wydaje się jednak, że dzieci, o których czytamy u Quirogi, wzorowane są na jego prawdziwych dzieciach, Eglé i Darío. Na taki stan rzeczy wskazują opisane w tekście okoliczności zamieszkania dzieci w obu baśniach - dzieci mieszkają jedynie z ojcem na farmie w lesie deszczowym. Tak właśnie wyglądało życie Quirogi po samobójstwie żony w 1911 roku, w czasie gdy pracował nad Cuentos de la seIva. Idąc tym tropem, pojawiającą się w wielu baśniach w zbiorze postać mężczyzny można interpretować jako ślad obecności samego Quirogi.

Martha Canfield w artykule Horacio Quiroga: La selva sagrada y el reino perfectible (Canfield, 1990) czyta wybrane opowiadania i powieści Quirogi, których akcja osadzona jest w lesie, jako terapeutyczne zapisy przemiany Quirogi jako człowieka i pisarza pod wpływem mieszkania w lesie deszczowym. Badaczka pisze, że w przypadku Quirogi poddanie się prawom natury pozwala nie tyle na odnalezienie tożsamości indywidualnej, co pierwotnej tożsamości człowieka jako części świata przyrody. Istniejące w twórczości Quirogi napięcie pomiędzy społeczeństwem a naturą opisują także Luis Martul Tobío i Kathleen March w artykule Ejes del pensamiento del Horacio Quiroga (March, Martul Tobío, 1987), również interpretując twórczość Quirogi jako poszukiwanie początku i pierwotnej roli człowieka w przyrodzie.

Przeciwstawiający się społeczeństwu mężczyzna z Cuentos de la selva wpisuje się w stworzoną przez wymienionych badaczy narrację na temat stosunku Quirogi do natury i kultury. Niezależnie od tego, w jakim stopniu bohaterowie Quirogi są tożsami 
z autorem, w jego twórczości na różne sposoby powraca temat naturalnego porządku i miejsca człowieka w przyrodzie, przez Canfield przedstawiony jako obsesja literatury hispanoamerykańskiej wiecznie próbującej powrócić do tego, co było przed kolonizacją. Przy takim odczytaniu Quiroga jest typowym twórcą Ameryki Południowej, niezależnie od liczby nawiązań do literatury europejskiej w sferze strukturalnej, fabularnej i alegorycznej.

Podążanie za wzorcami europejskimi wciąż pozostaje jednak pewnym faktem powracającym w twórczości Quirogi, od którego też sam autor wcale się nie odżegnywał. Tego rodzaju europeizacja opowieści o argentyńskim lesie pozostaje niepodważalnym literackim świadectwem kolonizacji. Z tej perspektywy na współczesny los zbioru Cuentos de la selva infantylizowany w podobny sposób co baśnie europejskie patrzeć można jako na kolejny etap zdominowania opowieści z Ameryki Południowej przez narrację europejską.

\section{Literatura:}

Arévalo Viveros D.F., 2019. El cuento es la selva: lectura crítica-ecológica de los Cuentos de la selva de Horacio Quiroga. $452^{\circ} \mathrm{F}, 20$ (1), 121-132.

Canfield M.L., 1990. Horacio Quiroga: La selva sagrada y el reino perfectible, Revista de la Universidad Nacional, 24 (6), 31-34.

Clements R., Musker J., 1989. Mata syrenka (The Little Mermaid), USA.

Darnton R., 2012. Wielka masakra kotów i inne epizody francuskiej historii kultury, Warszawa, PWN.

Finocchiaro A., 2018. Prólogo, Cuentos de la selva, Buenos Aires, Ministerio de Educación.

Franco J. (red.), 1993. Historia de la Literatura Hispanoamericana, Barcelona, Ariel.
Kipling R., 1950. Księga dżungli, przeł. J. Birkenmajer, Warszawa, Wydawnictwo Polskie R. Wegner.

Łebkowska A., 2007. Między antropologia literatury $i$ antropologiq literacka, Teksty Drugie, 6, 6-23.

March K.N., Martul Tobío L., 1987. Ejes del pensamiento del Horacio Quiroga, Cuadernos Hispanoamericanos, 443 (5), 73-87.

Ortiz Aguirre E., 2017. Por qué el cuento alcanza como género uno de sus cotas más altas en la literatura hispanoamericana?, La literatura hispanoamericana en 100 preguntas, Madryt, Nowtilus.

Quiroga H., 1950. Opowieści leśne, tł. H. Bychowska, Warszawa, Nasza księgarnia.

Quiroga H., 1976. Opowieści z selwy, Opowiadania o mitości, szaleństwie $i$ śmierci, przeł. Z. Wasitowa, Warszawa, PIW.

Quiroga H., 2018. Cuentos de la selva, Buenos Aires, Ministerio de Educación.

\section{Źródła internetowe:}

Biografia Horacia Quirogi na stronie
Escritores.org https://www.escritores.org/biografias/24 7-horacio-quiroga [Dostęp: 6.01.20].

Rogers C., Quiroga, Kipling, and the Exotic Frontier: A Comparative Study [eng] http://userwww.sfsu.edu/clsa/portals/20 06/rodgers.html [Dostęp: 6.01.20].

Urcid Serrano J., El simbolismo del jaguar on el suroeste de Mesoamérica [esp] https://arqueologiamexicana.mx/mexico -antiguo/el-simbolismo-del-jaguar-enel-suroeste-de-mesoamerica [Dostęp: 6.01.20].

Notka o autorce: Agnieszka Możejko to magister filologii polskiej pracujaca zawodowo jako redaktor i korektor. Do jej zainteresowań należa rękodzieło, malarstwo i kultura popularna. 
Aneks

\section{Pończochy flamingów}

Pewnego razu żmije wydały wielki bal. Zaprosiły żaby, ropuchy, flamingi, kajmany żakare i ryby. Ryby oczywiście nie mogą chodzić i tym samym nie mogą tańczyć, ale bal odbywał się na brzegu rzeki, więc uczestniczyły w zabawie, wychylając się na piasek i klaszcząc ogonami.

Kajmany paradowały w ozdobnych kołnierzach z bananów, popalając paragwajskie cygara. Ropuchy całe swoje ciała przybrały rybimi łuskami, które trzęsły się z każdym krokiem, sprawiając wrażenie, jakby ropuchy pływały po lądzie, a nie chodziły. Zawsze, gdy mijały brzeg rzeki, ryby rzucały w ich stronę uszczypliwe uwagi, naśmiewając się z nich.

Żaby całe się wyperfumowały i zaczęły chodzić na dwóch nogach. Do tego każda zawiesiła sobie na szyi świetlika kołyszącego się jak latarenka.

Najpiękniejsze były jednak żmije. Każda bez wyjątku była ubrana w kostium baleriny w kolorze swojej skóry. Czerwone żmije przywdziały rozłożyste spódnice, pollery, z czerwonego tiulu, zielone żmije z zielonego tiulu, a żółte z żółtego. Żararaki założyły pollery z siwego tiulu pomalowanego w pasy pyłem z cegieł i popiołu, bo takie kolory właśnie mają węże żararaki. Najbardziej olśniewająco ze wszystkich wyglądały koralowe żmije, które ubrały się w suknie z długimi szyfonowymi wstęgami, czerwonymi, białymi i czarnymi, które falowały jak serpentyny. Kiedy żmije obracały się w tańcu, wirując na czubkach ogonów, wszyscy zaproszeni bili im niesamowite brawa.

Tylko flamingi, które miały wtedy jeszcze nogi białe, a dzioby, tak jak i teraz, niezwykle grube i krzywe, tylko flamingi były smutne, bo, jako że nie były zbyt inteligentne, nie wiedziały, jak mogłyby się przyozdobić. Zazdrościły wszystkim pięknych strojów, a najbardziej koralowym żmijom. Za każdym razem, gdy któraś ze żmij przepełzała przed nimi, kokietując i trzepocząc wstęgami, flamingi umierały z zazdrości.

Jeden z flamingów stwierdził:

- Wiem, co musimy zrobić. Musimy znaleźć sobie czerwono-biało-czarne pończochy, a koralowe żmije wprost się w nas zakochają!

Wszystkie naraz poderwały się do lotu, przeleciały nad rzeką i wylądowały pod sklepem w pobliskiej wiosce.

Puk, puk! - zastukały do drzwi.

- Kto tam? - odpowiedział sklepikarz.

- Tu flamingi. Czy można u pana kupić czerwono-biało-czarne pończochy?

- Nie, nie mamy takich - odrzekł sklepikarz. - Skąd ten pomysł? Nigdzie nie znajdziecie takich pończoch.

Flamingi wybrały się więc do kolejnego sklepu.

Puk, puk! Czy można tu kupić czerwono-biało-czarne pończochy?

Na co sklepikarz odpowiedział:

- Co mówicie? Czerwono-biało-czarne? Nigdzie nie znajdziecie takich pończoch. Skąd u państwa ten pomysł? Kim jesteście?

- Jesteśmy flamingami - odpowiedziały.

Mężczyzna odrzekł:

- To z pewnością jesteście flamingami z dziwnymi pomysłami. 
Odwiedziły więc kolejny sklep.

Puk, puk! Czy można tu kupić czerwono-biało-czarne pończochy?

Sklepikarz zawołał:

- W jakim kolorze? Czerwono-biało-czarne? Tylko ptaki z naprawdę dziwnymi pomysłami, takie jak wy, myślą o pytaniu o podobne pończochy. Wynocha stąd!

I wtedy sklepikarz pogroził im miotłą.

Flamingi obeszły wszystkie sklepy i we wszystkich uznano ich pomysły za dziwaczne.

Spotkały jednak pancernika, który szedł właśnie nad rzekę, by napić się wody. Pancernik chciał ponabijać się z flamingów, wykonał wielki pokłon i zaczął mówić:

- Dobry wieczór, panowie flamingowie! Wiem dokładnie, czego państwo szukają! W żadnym sklepie nie znajdziecie takich pończoch. Być może w Buenos Aires, ale musieliby państwo złożyć zamówienie pocztowe. Za to moja szwagierka, sowa, ma właśnie takie pończochy. Tylko zapytajcie, a na pewno da panom czerwono-biało-czarne pończochy.

Flamingi podziękowały i pofrunęły w stronę dziupli sowy. Tak jej powiedziały:

- Dobry wieczór, sowo! Przyszliśmy poprosić o czerwono-biało-czarne pończochy. Dzisiaj żmije wydały wielki bal i jeśli będziemy mieć te pończochy, to koralowe żmije wprost się w nas zakochają.

- Z wielką przyjemnością! - odrzekła sowa. - Zaczekajcie sekundę, zaraz wrócę.

Zerwała się do lotu i zostawiła flamingi same. Po krótkiej chwili wróciła z pończochami. Tylko że to nie były pończochy, ale skóry koralowych żmij - świeżo zerwane skóry żmij, które upolowała sowa.

- Oto wasze pończochy! - powiedziała sowa. - Niczym się nie przejmujcie, pamiętajcie tylko o jednym: tańczcie całą noc, tańczcie, nie przerywając ani na moment. Tańczcie na bokach, na dziobach, na głowie, jak tylko chcecie, ale nie zatrzymujcie się ani na chwilę, bo zamiast tańczyć, będziecie płakać.

Ale flamingi, jako że nie były zbyt mądre, nie zrozumiały, jak wielki ból może je czekać i, nie posiadając się ze szczęścia, założyły skóry koralowych żmij jak pończochy, wsuwając je na nogi jak tuby. Bardzo ucieszone wróciły na bal.

Gdy goście zobaczyli flamingi w pięknych pończochach, natychmiast poczuli zazdrość. Żmije chciały tańczyć tylko z nimi, ale, jako że flamingi nie przestawały poruszać nogami, nie były w stanie dostrzec, z czego zrobione były ich wspaniałe pończochy.

Jednak z czasem żmije zaczęły się czegoś domyślać. Kiedy flamingi przesuwały się przed nimi w tańcu, nachylały się ku ziemi, aby zyskać lepszy widok.

Spośród wszystkich żmij koralowe żmije miały najwięcej podejrzeń. Nie spuszczały z oczu pończoch i próbowały się przyczaić, aby z odległości dosięgnąć językiem (który jest dla żmii jak ręka dla człowieka) nóg flamingów. Ale flamingi tańczyły i tańczyły bez końca, pozostawało tylko czekać aż się zmęczą i nie będą już mogły więcej.

Koralowe żmije coraz bardziej utwierdzały się w swoich przypuszczeniach. Poprosiły żaby o pożyczenie świetlików i czekały, aż flamingi padną za zmęczenia.

Rzeczywiście, minutę później flaming, który nie mógł już więcej tańczyć, potknął się o cygaro jednego z kajmanów, zatoczył się i upadł ze zmęczenia. Po chwili koralowe żmije podpełzły do niego a zaraz za nimi podleciały świetliki, dzięki którym żmije mogły dojrzeć w ciemności nogi flaminga.

Teraz wyraźnie widziały, że flaming wcale nie miał na sobie pończoch i wydały z siebie lament tak głośny, że słychać go było na drugim brzegu Parany.

- To nie pończochy! - krzyczały żmije - Wiemy, co to jest! Oszukano nas! Flamingi zamordowały nasze siostry i teraz noszą ich skóry na nogach! To pończochy z koralowych żmij! 
Po usłyszeniu tego przerażone wyjściem na jaw prawdy flamingi chciały uciekać, ale były tak zmęczone, że nie mogły podnieść nawet jednej nogi. Właśnie wtedy koralowe żmije rzuciły się na flamingi, oplotły ich łapy swoimi ciałami i zaczęły gryźć i niszczyć pończochy. Zrywały je z flamingów po kawałku, wściekle wbijając się kłami w nogi ptaków, aby pomścić swoje siostry.

Flamingi, miotając się w bólu, skakały z jednej nogi na drugą, próbując zrzucić z nóg koralowe żmije. W końcu zmęczone żmije zobaczyły, że nic już nie zostało z pończoch, puściły wolno flamingi i zaczęły poprawiać swoje suknie balowe.

Były pewne, że flamingi wkrótce umrą, bo co najmniej połowa ze żmij była jadowita.

Flamingi jednak nie umarły. Wbiegły do wody, nieprzerwanie czując wielki ból w nogach, które przedtem były białe, a teraz stały się czerwone na skutek działania jadu żmij. Mijały dnie i dnie, a flamingi wciąż czuły, jakby ich nogi były palone żywym ogniem. Ich nogi, w których krążyła trucizna, nabrały koloru krwi na zawsze.

I aż do teraz flamingi spędzają całe dnie, nurzając swoje czerwone nogi w wodzie, próbując ukoić ból, który nieustannie w nich czują. Czasem wychodzą na brzeg i stawiają kilka kroków na ziemi, żeby sprawdzić, czy znów mogą chodzić po lądzie. Wtedy jednak nogi znów zaczynają boleć od trucizny, więc flamingi biegną z powrotem do rzeki. Czasem ból jest tak silny, że na długie godziny podnoszą w górę jedną nogę, bo nie są w stanie na niej stać.

To jest historia flamingów, które niegdyś miały białe nogi, a teraz mają czerwone. Wszystkie ryby ją znają, dlatego się z nich śmieją. Kojące swój ból w wodzie ptaki nie odpuszczają jednak żadnej okazji do zemsty i zjadają każdą śmiejącą się rybkę, która podpłynie zbyt blisko.

\section{Oskubana papuga}

Było sobie stadko papug, które mieszkało w dżungli. Wczesnym rankiem wybierały się na farmę, zjeść trochę kukurydzy, a wieczorem pożywiały się pomarańczami. Robiły przy tym dużo hałasu swoim skrzeczeniem, dlatego zawsze jedna z papug siadała wysoko w drzewach jako strażniczka, żeby ostrzec pozostałe, gdyby ktoś się zbliżał.

Papugi są tak samo szkodliwe jak langusty, bo otwierają kolby dziobami, przez co kukurydza potem gnije na deszczu i nie nadaje się już do jedzenia. Za to gulasz z papugi smakuje wyśmienicie, więc farmerzy nie próbowali ich przepędzać, ale upolować.

Pewnego dnia farmer strzelił do papugi stojącej na straży, a ona upadła zraniona. Mimo rany walczyła, zanim pozwoliła się schwytać. Mężczyzna w końcu jednak zaniósł ją do domu i tam zostawił pod opiekę dzieci, które wyleczyły jej złamane skrzydło - nic więcej jej nie dolegało. Z czasem papuga doszła do siebie i pozwoliła całkowicie się oswoić, a dzieci nadały jej imię Pedrito. Nauczyła się podawać łapkę, lubiła siadywać na ramionach ludzi i łaskotać ich dziobem za uchem.

Żyła wolno i spędzała całe dnie, latając pomiędzy pomarańczami i eukaliptusami w ogrodzie, lubiła też robić sobie żarty z kur. O czwartej czy piątej po południu, gdy w domu przychodziła pora na herbatę, ona również udawała się do salonu i wspinała się za pomocą dzioba i nóg na obrus, aby zajadać się chlebem nurzanym w herbacie z mlekiem. Wprost przepadała za herbatą z mlekiem.

Pedrito dostawał od dzieci, co tylko chciał i uczył się mówić, powtarzając wszystko to, co one mówiły. Mówił: „Dzień dobry, papużko!”, „Ale pycha!”, „Chlebek dla Pedrito!”. Mówił też dużo rzeczy, 
których nie powinien był mówić, bo papugi, podobnie jak dzieci, z dużą łatwością uczą się mówić brzydkie słowa.

Kiedy padał deszcz, zwijał się w kulkę i przez krótką chwilę mówił sam do siebie te wyuczone słowa. Kiedy ta chwila mijała, zaczynał latać, krzycząc wściekle.

Był, jak widać, bardzo szczęśliwą papugą, która po tym jak była wolna, tak jak tego chcą wszystkie ptaki, piła herbatkę o piątej jak bogaci ludzie.

Pewnego popołudnia kolejnego dnia szczęśliwego życia Pedrito po pięciu dniach ulewy wyszło słońce i papuga zaczęła latać, krzycząc: „Mamy piękny dzień, papużko!”, „Ale pycha!”, „Podaj łapkę, Pedrito!". Nie odlatywał daleko, dopóki nie zobaczył w dali, gdzieś w dali, rzeki Parany, która wydawała się z góry długą i szeroką białą wstążką. Leciał dalej i dalej, aż napotkał drzewo, na którym postanowił odpocząć.

Nagle spomiędzy gałęzi zobaczył coś błyszczącego na ziemi. Dwa zielone światła jakby olbrzymie świetliki.

- Co tam? - zapytała papuga. - Ale pycha! Co to jest? Dzień dobry, Pedrito.

Papuga zawsze tak mówiła, jak wszystkie inne papugi mieszając słowa bez ładu i składu tak, że ciężko ją było zrozumieć. A jako że była bardzo ciekawska, zeszła na dół gałąź po gałęzi, żeby się zbliżyć.

Wtedy zobaczyła, że te dwa światła były w istocie oczami jaguara czuwającego pod drzewem. Pedrito był jednak tak ucieszony z pięknego dnia, że nie odczuwał w ogóle strachu.

- Mamy piękny dzień, jaguarze! - powiedział. - Podaj łapkę, Pedrito!

Jaguar odpowiedział swoim zachrypłym głosem:

- Dzień do-bry!

- Dzień dobry, jaguarze! - powtórzył Pedrito. - Ale pycha! Ale pycha! Ale pycha!

I powiedział jeszcze kilka razy „Ale pycha!”, bo była już czwarta po południu i miał coraz większą ochotę wypić herbatę z mlekiem. Pedrito zapomniał, że leśne zwierzęta nie urządzają popołudniowej herbatki i zaczął zapraszać jaguara.

- Smacznej herbaty z mlekiem! - powiedział. - Dzień dobry, Pedrito! Chcesz się napić ze mną herbaty z mlekiem, przyjacielu jaguarze?

Jaguar rozwścieczył się, bo był pewien, że papuga się z niego naśmiewa, a jako że był głodny, zapragnął zjeść gadającego ptaka. Odpowiedział papudze:

- Pe-wnie! Ale po-dejdź trochę ni-żej, je-stem głuchy.

Jaguar wcale nie był głuchy. Chciał jedynie, aby Pedrito zbliżył się na tyle, by można go było schwytać pazurami. Ale papuga wcale o tym nie myślała, w głowie miała tylko wspomnienie smaku domowego podwieczorku i chciała napić się herbaty z mlekiem z tak wspaniałym przyjacielem. Przeskoczyła na kolejną gałąź, tuż przy ziemi.

- Pyszny chlebek w domu! - krzyknęła tak głośno, jak mogła.

- Zejdź ni-żej, nie sły-szę - odrzekł jaguar.

Biedna papuga zleciała niżej i właśnie w tym momencie jaguar wykonał wielki skok, tak wielki jak dom, i wylądował tuż przy pazurkach Pedrito. Nie zabił go od razu, ale zdarł mu wszystkie pióra z pleców i ogona. Nie zostało ani jedno piórko w ogonie papugi.

- Na-pij się! - śmiał się jaguar. - Idź się na-pić herba-ty z mle-kiem...

Papuga, krzycząc z bólu i strachu, poderwała się do lotu, ale nie mogła zbyt dobrze lecieć, bo brakowało jej piór w ogonie, a ogon jest dla ptaka jak ster. Leciała, kołysząc się w powietrzu z boku na bok i wszystkie ptaki, które spotykała, bały się tak dziwnego stworzenia. 
W końcu dotarła do domu i pierwsze, co zrobiła, to obejrzała się w lustrze kucharki. Biedny Pedrito! Był najdziwniejszym i najbrzydszym ptakiem, jaki tylko może istnieć. Taki łysy, pozbawiony ogona i trzęsący się z zimna. Jak miał pojawić się w salonie w takim stanie? Wyleciał na zewnątrz, w stronę pnia eukaliptusa, w którym była dziupla, i tam się ukrył, dygocząc z zimna i wstydu.

Tymczasem w salonie wszyscy zauważyli brak Pedrito. „Gdzie jest Pedrito?” - pytali. „Pedrito! Mamy dla ciebie pyszny chlebek, Pedrito! Herbata z mlekiem na ciebie czeka, Pedrito!" - nawoływali.

Ale Pedrito nie wychylał się ze swojej dziupli i nic nie odpowiadał; trwał w ciszy i bezruchu. Szukali go wszędzie, ale papugi nigdzie nie było.

Wszyscy doszli do wniosku, że Pedrito musiał umrzeć, co doprowadziło dzieci do płaczu.

Każdego popołudnia w porze na herbatę wspominali papugę i opowiadali sobie o tym, jak lubiła jeść chleb moczony w herbacie z mlekiem. Biedny Pedrito! Nigdy więcej go nie zobaczą, bo już nie żyje.

Ale Pedrito dalej żył, tylko wciąż ukrywał się w dziupli, bo był zbyt zawstydzony, żeby pokazać się goły jak szczur. Wychodził tylko nocą, żeby coś zjeść, i zaraz potem wracał do dziupli.

O świcie, kiedy już robiło się widno, mógł przeglądać się w lustrze kucharki i robiło mu się jeszcze smutniej, bo pióra bardzo wolno odrastały.

W końcu jednak, pewnego wieczoru lub popołudnia, kiedy rodzina siadała do stołu na herbatę, niespodziewanie do pokoju wszedł Pedrito, spokojny i dumny, jakby nic się nie stało. Wszyscy oniemieli z zachwytu, gdy zobaczyli go żywego i porośniętego pięknymi piórami.

- Pedrito, papużko! - zawołali. - Gdzie byłeś, Pedrito? Jakie piękne masz pióra!

Nie wiedzieli, że to były nowe pióra, a Pedrito niczego nie wyjaśniał. Po prostu jadł chleb moczony w herbacie z mlekiem. I nie odzywał się słowem.

Pan domu bardzo się więc zdziwił, kiedy następnego ranka papuga wleciała na jego ramię i zaczęła gadać jak nakręcona. W dwie minuty opowiedziała o wszystkim, co się wydarzyło. O podróży do Paragwaju, spotkaniu z jaguarem i całej reszcie. Każdy epizod podsumowywała, mówiąc:

- Ani piórka w ogonie Pedrito! Ani piórka! Ani piórka!

I zaproponowała, żeby wyruszyli we dwóch upolować jaguara.

Pan domu właśnie w tym momencie myślał o zakupie skóry jaguara, bo chciałby sobie taką położyć przed kominkiem, był więc bardzo kontent, że może zdobyć ją za darmo. Wrócił do domu po strzelbę i wyruszył z Pedrito w podróż do Paragwaju. Zaplanowali, że kiedy Pedrito zobaczy jaguara, zajmie go rozmową, aby mężczyzna miał czas na zbliżenie się ze strzelbą.

Jak postanowili, tak zrobili. Papuga usiadła na gałęzi drzewa, czekała i czekała, spoglądając na wszystkie strony, próbując wypatrzyć jaguara. Aż nagłe poczuła poruszenie w niższych gałęziach i zobaczyła pod drzewem dwa zielone światła wymierzone wprost na nią - to były oczy jaguara.

Wtedy Pedrito zaczął wykrzykiwać:

- Piękny dzień mamy! Ale pycha! Pyszna herbata z mlekiem! Czy masz ochotę na herbatę z mlekiem?

Jaguar rozdrażnił się, przypominając sobie papugę, którą oskubał i sądził, że zostawił na pewną śmierć, a która ma teraz piękne nowe pióra. Przysiągł sobie, że teraz mu nie ucieknie, a jego oczy zapłonęły. Odpowiedział papudze swoim zachrypłym głosem:

-Zejdź ni-żej, nie sły-szę.

Papuga zeszła o gałąź niżej i krzyknęła:

- Pyszny chleb z mlekiem! JEST PRZY KORZENIACH DRZEWA!

Słysząc te ostatnie słowa, jaguar ryknął i rzucił się do skoku.

- Do kogo mówisz? - zawarczał. - Komu mówisz, że jestem przy korzeniach drzewa?

- Nikomu, nikomu - krzyknęła papuga. - Dzień dobry, Pedrito! Podaj łapkę, papużko! 
Kontynuowała krzyczenie i przeskakiwanie z gałęzi na gałąź, zbliżając się do jaguara. Mówiła oczywiście do mężczyzny, z którym wybrała się na polowanie i który dobrze się schował w krzakach ze strzelbą na ramieniu. Nadszedł moment, kiedy papuga już nie mogła się bardziej zbliżyć, bo wpadłaby w paszczę jaguara i właśnie wtedy zawołała:

- Ale pycha! UWAGA!

- Jeszcze tro-chę bli-żej! - zaryczał jaguar, czając się do skoku.

- Pyszna herbata z mlekiem! UWAGA, ZARAZ SKOCZY!

I jaguar rzeczywiście skoczył. Oddał ogromny sus, przed którym papuga uskoczyła w powietrzu niczym strzała. W dokładnie tym samym momencie mężczyzna opierający lufę strzelby o pień, żeby skuteczniej wycelować, pociągnął za spust i dziewięć kul wielkości ziaren ciecierzycy każda jedna trafiły prosto w serce jaguara, który wydał z siebie ryk tak potężny, że zatrząsł całym lasem, i padł martwy.

A jak Pedrito krzyczał z radości! Wprost nie posiadał się ze szczęścia, bo dokonał zemsty - i to jakiej! - na obrzydłym zwierzęciu, które pozbawiło go piór.

Mężczyzna również był szczęśliwy, bo zabicie jaguara to prawdziwe wyzwanie. No i miał teraz skórę do położenia przed kominkiem w salonie. Kiedy pojawił się w domu, wszyscy dowiedzieli się, dlaczego Pedrito tak długo chował się w dziupli i teraz byli radzi z jego sukcesu.

Żyli dalej bardzo szczęśliwi, ale papuga nigdy nie zapomniała, co wydarzyło się między nią a jaguarem i każdego popołudnia, kiedy wchodziła do salonu, żeby napić się herbaty, zawsze podchodziła do skóry jaguara leżącej przed kominkiem i zapraszała go na herbatkę.

- Ale pycha! - mówiła. - Czy masz ochotę na herbatę z mlekiem? Chlebek dla jaguara!

I wszyscy umierali ze śmiechu. Pedrito również. 